\title{
Article
}

\section{Earthworm dispersal of plant litter across the surface of agricultural soils}

\author{
Nuutinen, Visa and Butt, Kevin Richard \\ Available at https://clok.uclan.ac.uk/26284/ \\ Nuutinen, Visa and Butt, Kevin Richard orcid iconORCID: 0000-0003-0886- \\ 7795 (2019) Earthworm dispersal of plant litter across the surface of \\ agricultural soils. Ecology, 100 (7). ISSN 0012-9658
}

It is advisable to refer to the publisher's version if you intend to cite from the work. http://dx.doi.org/10.1002/ecy.02669

For more information about UCLan's research in this area go to

http://www.uclan.ac.uk/researchgroups/ and search for < name of research Group>.

For information about Research generally at UCLan please go to http://www.uclan.ac.uk/research/

All outputs in CLoK are protected by Intellectual Property Rights law, including Copyright law. Copyright, IPR and Moral Rights for the works on this site are retained by the individual authors and/or other copyright owners. Terms and conditions for use of this material are defined in the policies page.

\section{CLoK}

Central Lancashire online Knowledge www.clok.uclan.ac.uk

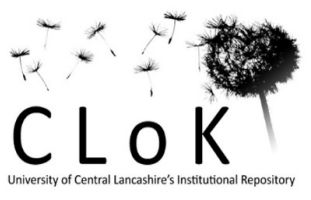


Running Head and Manuscript Type: The Scientific Naturalist

\section{Earthworm dispersal of plant litter across the surface of agricultural soils}

Visa Nuutinen $^{1 *}$ and Kevin R. Butt ${ }^{2}$

${ }^{1}$ Soil Ecosystems, Natural Resources Institute Finland (Luke), FI-31600, Jokioinen, Finland

${ }^{2}$ School of Forensic and Applied Sciences, University of Central Lancashire, Preston

PR1 2HE, United Kingdom

*Corresponding author: visa.nuutinen@luke.fi

When we observed earthworms (Lumbricus terrestris L.; the dew worm or nightcrawler), foraging on patchily distributed plant residues in the laboratory, we noticed an exceptional interaction in their acquisition of dead organic matter. We review this original observation and then relate a subsequent finding which indicates the importance of the phenomenon in the field.

This article has been accepted for publication and undergone full peer review but has not been through the copyediting, typesetting, pagination and proofreading process, which may lead to differences between this version and the Version of Record. Please cite this article as doi: 10.1002/ecy.02669

This article is protected by copyright. All rights reserved. 
While foraging on plant litter at the soil surface, dew worms keep their tail ends anchored in their burrows, rarely departing from and returning to the burrow (Nuutinen and Butt 2005). The length an individual can stretch from its burrow therefore determines the maximum radius of a dew worm's foraging area. For an adult dew worm that is close to $0.3 \mathrm{~m}$ (Nuutinen and Butt 1997). As part of a laboratory study, we provided dew worms with a patch of straw towards the corner of a square metre foraging arena occupied by 18 evenly distributed adult individuals (Butt et al. 2003). Many dew worms had their burrow openings too far from the patch to allow direct residue collection from it, yet these individuals also produced middens, piles of collected residue at their burrow openings. This resulted when the middens of individuals within a collection distance from the patch were foraged by their neighbours, which did not reach the patch directly. Their middens were subsequently foraged by individuals still farther away and this relay action distributed the original straw across the foraging arena.

In many temperate and boreal soils, dew worms are key bioturbators due to their efficient collection, burial and ingestion of plant litter. Their influence is particularly strong in deciduous forests where dew worm foraging alone may suffice for entire incorporation of litter fall (Nielsen and Hole 1964, Satchell 1967). It can be equally pronounced in conservation tilled and no-till arable fields where dew worms often abound (Subler and Kirsch 1998, Briones and Schmidt 2017). In natural habitats, plant litter is often patchily distributed (Facelli and Pickett 1991) and it is possible that the type of litter relay which we observed would affect litter distribution in habitats where dew worms live. Observational study of this is understandably difficult under dense and diverse natural vegetation.

An opportunity for such enquiry became available at the termination of a 30-year arable field experiment in Jokioinen, S-W Finland $\left(60^{\circ} 48.15^{\prime} \mathrm{N}, 23^{\circ} 28.09^{\prime} \mathrm{E}\right)$. In this split-plot experiment on a clay soil (Vertic Luvic Stagnosol), established in 1983, three residue 
management treatments (the whole-plot factor: residue collected away, left in the field or burnt) and two autumn tillage treatments (the split-plot factor: conventional mouldboard plowing or reduced tillage) were compared in spring cereal cultivation (Singh et al. 2015). The sizes of the individual plots were $4 \mathrm{~m} \times 15 \mathrm{~m}$ and the experiment was set up as a randomized complete block (RCB) design with four blocks.

The final cereal (barley) harvest of the experiment occurred in September 2012 by a single pass of a combined harvester along the plot center line. The residue was left on the ground in all treatments and the site remained unmanaged until the following spring. When the field was visited in May 2013, the beds of residue left by the harvester were still visible as c. meter wide stripes in the center of the plots. The presence of dew worms was revealed by their middens.

We compared dew worm density in the conventional mouldboard plowed and reduced tillage treatments in those plots where residue had been left during the experimental years. Dew worm middens were counted in $0.5 \mathrm{~m}^{2}$ squares $(\mathrm{N}=3)$ in each plot, immediately adjacent to the residue beds. Counting occurred in three of the four experimental blocks where conditions for reliable observations were most favourable on $24^{\text {th }}$ May 2013. Mean midden density in the reduced tillage plots was almost four times higher than where the plots were conventionally plowed (19 (s.d. 2.1) vs. 5 (3.6) middens $\mathrm{m}^{-2}$; F=32.3, P=0.03 (RCB ANOVA with GLM procedure of SAS 9.4)) (Fig. 1). During the following October, midden density was a satisfactory proxy for dew worm population density at the site (Singh et al. 2015).

Residue distributions in the reduced tillage and plowed plots suggested an intriguing difference in spatial pattern. In plowed plots, the residue beds in the plot centers appeared distinct and the plot margins were relatively devoid of residue (Fig. 1, left). By contrast, residue beds in reduced tillage plots were less distinct because residue was more evenly 
distributed (Fig 1, right), the residue being concentrated in dew worm middens at plot margin areas. On $9^{\text {th }}$ June 2013, surface residue samples were taken from each plot where dew worm middens were counted. Samples were collected with a sample frame of dimensions $0.57 \mathrm{~m}$ length (positioned along the length of the plot) x $0.37 \mathrm{~m}$ width. From each plot, samples were taken as three plot center - plot margin pairs. The center sample was taken at the plot middle line and the margin sample was taken at c. $0.5 \mathrm{~m}$ distance from the plot margin. The margin samples were thus taken from within a c. 0.3-0.7 m zone from the plot margin. The distance between the center and the margin sample middle points was $1.5 \mathrm{~m}$. All residue from the soil surface (excluding the smallest pieces such as awns and husks) was carefully collected into paper bags by hand and with forceps, avoiding inclusion of any crumbs of soil. Only above ground parts of partially soil covered pieces were included by cutting them with scissors. In the laboratory, samples were dried for five days at $50^{\circ} \mathrm{C}$ and stored at room temperature. Prior to mass determination, the samples were further cleaned of remaining soil with a fine brush and forceps.

Based on the residue dry mass, for each sample pair, we calculated the proportion of the residue in the plot margin area of the total dry mass and compared the mean proportion in plowed and reduced tillage. The result confirmed the visual observation of a more even distribution of residue in reduced tillage: the mean proportion of residue in the plot margin area in plowed plots was $25 \%$ (s.d. 4.9) and in reduced tillage plots $37 \%$ (s.d. 6.3) ( $\mathrm{F}=25.8$, $\mathrm{P}=0.0002$ ). The total residue dry mass of the pairs (center-line + margin) was somewhat lower in plowed plots compared with reduced tillage, but the difference was not statistically discernible (119 g (s.d. 26.8) vs. 133 g (11.9); F=2.47, $\mathrm{P}=0.138)$.

We suggest that more even distribution of residues in the reduced tillage treatment with high dew worm density resulted from the dew worm-induced relay movement of residue from the plot center towards the margins. This would indicate that apart from their known capacity to 
collect residue in middens - thus creating biological hot spots (e.g. Nuutinen et al. 2017) and to incorporate litter into the soil - thereby contributing to creation of a mull profile, nutrient cycling and carbon sequestration (e.g. Don et al. 2008) - the dew worm population in toto can redistribute litter at the scale of meters. We regard it unlikely that any other process could explain the observed difference in residue distribution. Dew worms at the plot margin areas of reduce tillage plots could increase the residue cover to some small degree by e.g. tearing loose lower leaves from the standing stubble, but such activity would be insufficient to produce the observed pattern.

The effect of dew worm population on litter dispersal can be enhanced by a number of factors. First of all, dew worms collect large amounts of litter in middens from which it is taken only gradually for consumption. This resembles food hoarding (Vander Wall 1990) although middens may serve not only nutritional functions but can also have protective, regulatory and maybe even display roles. Further, plant litter is an abundant, low quality and non-durable resource for which resource protection and concealment can be regarded unlikely (Strassman and Queller, 2014) should earthworms have the behavioral ability for such activity. In our field site, the spreading out of the residue could also have been accentuated by the excessive availability of plant remains at the residue beds and therefore minor "taking back" of residues by the original foragers. It is also possible that the nutritional quality of residue distributed away from residue bed becomes progressively lowered due to feeding by dew worms. This would reduce the "return movement" of residue if dew worms prefer less consumed litter.

The role of physical forces such as wind and water in the displacement and accumulation of litter are well established (Facelli and Pickett, 1991). Our finding suggests that biological processes, too, can have significance. The distribution of litter affects chemical, physical and biological soil conditions in ways which are reflected in plant community structure (Facelli 
and Pickett 1991) and it is conceivable that the dew worm residue relay has various ecological consequences in their living habitats. It can also intensify the effect that dew worms have on litter disappearance in the habitats which they invade (Suárez et al. 2006). For the distribution of dew worms in habitats with spatially varying residue quantity and quality, the residue relay could imply opportunity for wider local distributions than would otherwise be possible.

Dispersal of litter from midden to midden might happen across vast areas of deciduous forests in Europe and in North-America where the dew worm is invading (Suárez et al. 2006). Within those two geographical regions, the estimated area of no-till arable land with potentially high dew worm influence is 41 million hectares (Derpsch et al. 2010). Modern agricultural machinery distributes plant residues increasingly evenly across cereal fields but most of the post-harvest land remains striped by residue beds, in preparation for the earthworm residue relay.

\section{Acknowledgments}

We thank Oiva Hakala for his help in the treatment of the residue samples and Päivi Parikka and Harri Huhta for support. The helpful comments of two anonymous referees and the Editor are gratefully acknowledged. This study is a contribution of Doncontrol-study (Luke Project \#41007-00027500) funded by the Ministry of Agriculture and Forestry of Finland.

This article is protected by copyright. All rights reserved. 


\section{Literature Cited}

Briones, M.J.I., and O. Schmidt. 2017. Conventional tillage decreases the abundance and biomass of earthworms and alters their community structure in global meta-analysis. Global Change Biology 23: 4396-4419.

Butt, K.R., V. Nuutinen, and T. Sirén. 2003. Resource distribution and surface activity of adult Lumbricus terrestris in an experimental system. Pedobiologia 47: 548-553.

Derpsch, R., T. Friedrich, A. Kassam, and L. Hongwen. 2010. Current status of adoption of no-till farming in the world and some of its main benefits. International Journal of Agricultural and Biological Engineering 3: 1-25.

Don, A., B. Steinberg, I. Schöning, K. Pritsch, M. Joschko, G. Gleixner, and E.-D. Schultze. 2008. Organic carbon sequestration in earthworm burrows. Soil Biology and Biochemistry 40: $1803-1812$.

Facelli, J.M., and S.T.A. Pickett. 1991. Plant litter: Its dynamics and effects on plant community structure. The Botanical Review 57: 1-32.

Nielsen, G.A., and F.E. Hole. 1964. Earthworms and the development of coprogenous Ahorizons in forest soils of Wisconsin. Soil Science Society of America Proceedings 28: 426430.

Nuutinen V., and K.R. Butt. 1997. Mating behaviour of the earthworm Lumbricus terrestris L. (Oligochaeta: Lumbricidae). Journal of Zoology (Lond.) 242: 783-798.

Nuutinen, V., and K.R. Butt. 2005. Homing ability widens the sphere of influence of the earthworm Lumbricus terrestris L.. Soil Biology \& Biochemistry 37: 805-807.

Nuutinen, V., K.R. Butt, J. Hyväluoma, E. Ketoja, and J. Mikola. 2017. Soil faunal and 
structural responses to the settlement of a semi-sedentary earthworm Lumbricus terrestris in an arable clay field. Soil Biology and Biochemistry 115: 285-296.

Satchell. J.E. 1967. Lumbricidae. In: Burgess, A., \& Raw, F. (Eds.). Soil Biology. Academic Press, London. Pp. 259-322.

Singh, P., J. Heikkinen, E. Ketoja, V. Nuutinen, A. Palojärvi, J. Sheehy, M. Esala, S. Mitra, L. Alakukku, and K. Regina. 2015. Tillage and crop residue management methods had minor effects on the stock and stabilization of topsoil carbon in a 30-year field experiment. Science of the Total Environment 518-519: 337-344.

Strassmann, J.E., and D.C. Queller. 2014. Privatization and property in biology. Animal Behaviour 92: 305-311.

Suárez, E.R., T.J. Fahey, J.B. Yavitt, P.M. Groffman, and P.J. Bohlen. 2006. Patterns of litter disappearnce in a northern hardwood forest invaded by exotic earthworms. Ecological Applications 16: 154-165.

Subler, S., and A.S. Kirsch.1998. Spring dynamic of soil carbon, nitrogen, and microbial activity in earthworm middens in a no-till cornfield. Biology and Fertility of Soils 26: 243249.

Vander Wall, S.B. 1990. Food Hoarding in Animals. The University of Chicago Press, Chicago and London.

This article is protected by copyright. All rights reserved. 


\section{Figure legend}

Figure 1. Study plots with low (mouldboard plowing (CT), left) and high (reduced tillage (RT), right) dew worm density. The photos were taken from the edge towards the plot center (dotted line) with the residue bed left by the combined harvester. The arrow indicates the direction of harvest. In the CT plot, the margin area has little residue, in the RT plot, residue is more evenly distributed across the plot. The bar charts show the mean density of dew worm middens (+s.d.; above) and mean proportion of straw at margin (+s.d.; below).
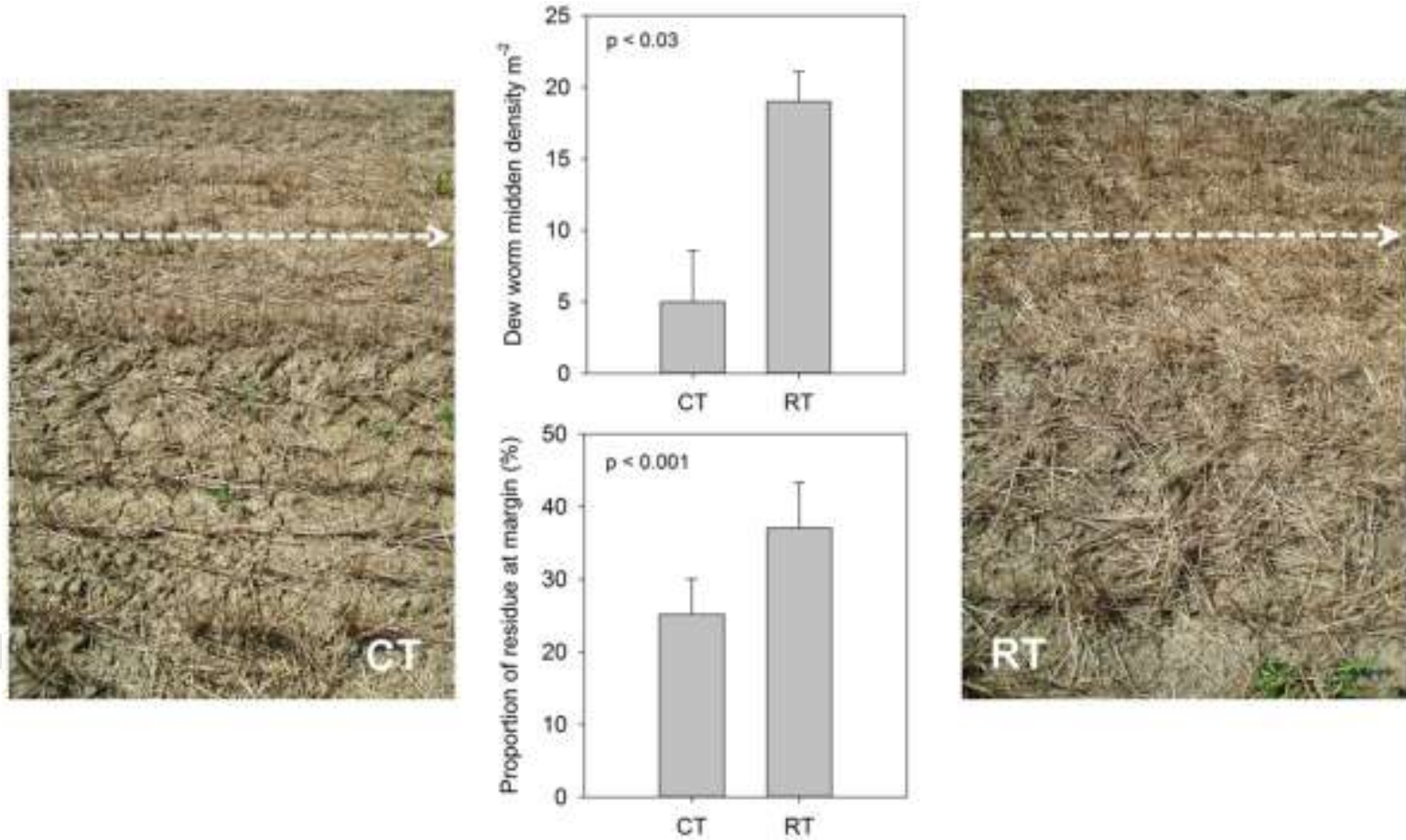

This article is protected by copyright. All rights reserved. 